\title{
Memoir of the Oxford Trip
}

\author{
Henry J.M. Barnett
}

Can J Neurol Sci. 2014; 41: 130-132

Since the Memoirs and the Epic Journey of University of Toronto Class 4T4 were printed, a remarkable event has engulfed me. Its significance is such that I feel compelled to add some details to both publications in their internet format. This is done with the urging and consent of my associates:

I was astonished in October 2011 to receive from the Chancellor's office of Oxford University an indication that they wished to present me with a degree of Honorary Doctor of Science. Until I heard that a body called "The Congregation" approved of the plan I was to say nothing about it. Accordingly I shared it only with my family and fellow writers.

Before the year-end, approval was sent and with a new lightweight wheelchair and my two sturdy sons we set out on June 17 to Heathrow by Air Canada (me business class and they steerage). We had rooms at the Royal College of Physicians house near Regent's Park (once an honorary member always a member). (Figure 1) Reasonable for downtown London as prices

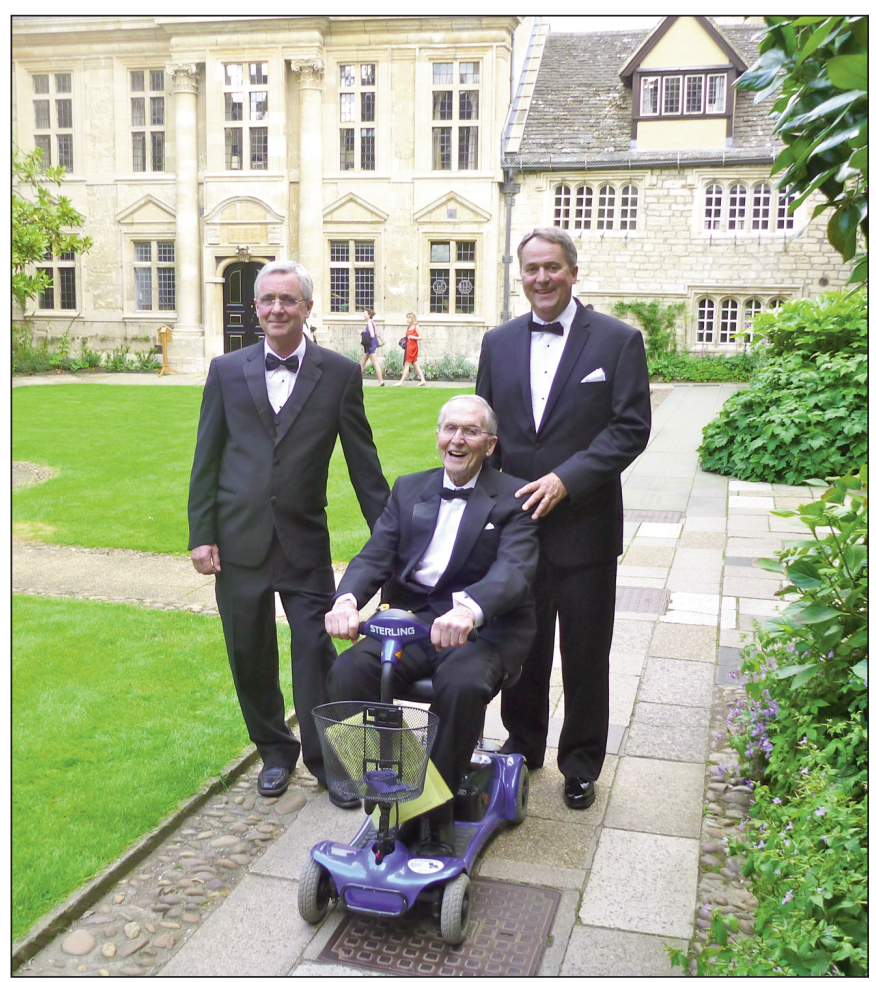

Figure 1: (from L.) William Barnett (son), Henry Barnett and Ian Barnett (son) had already risen anticipating the upcoming Olympics. Will and Ian snatched a half-day along the Embankment, Westminster Hall, etc. and in late afternoon we all went by train to Oxford. All of us were accommodated in St. Edmunds Hall tended by its friendly and gracious President, Professor Keith Gull.

All members of the Congregation and the honorees assembled for a centuries-old custom to partake of champagne, peaches and strawberries, to meet each other and the Chancellor in the courtyard of Exeter College. I was then pushed in the new chair to the Sheldonian Theatre. The route included cobblestones sufficiently unfavorable to the foot-rests of my chair that they came apart. Riding several blocks over cobble-stones with feet held in front was a good exercise and test of the thigh muscles.

Customarily at this rigidly handled function which is given the Greek name Encaenia (traditionally translated as "a festival of dedication") they recognize benefactors and give honorary degrees usually to seven academics but after Aung Suu Kyi (Daw Suu) was assured of her return to Burma by visa we became eight. These are considered the choice of the Congregation and represent distinguished literary persons, physical and medical scientists, theologians, artists, musicians, judiciary and business persons of special note.

In front of the Congregation the most senior undergraduate prizes were read out in Latin by the Public Orator and presented from all colleges and disciplines. This year they numbered 11 including law, statistics, fine art, psychology and medicine.

The eight of us were lined up along the main aisle of the Theatre and when our names was called we were escorted to the front. A few steps above were the Chancellor, Lord Patten of Barnes. First to go up to be hooded was Aung Suu Kyi from Burma, attempting to restore democracy to her country, with what can optimistically be described as early success. As a rare departure from tradition of many centuries she was invited to address the Congregation. Next came Baroness ManninghamBuller recently retired as head of MI5 (Britain's Security Service), then David Cornwell (Pen-name John Le Carré), author of famous spy stories, Madam Drew Faust, (President of Harvard University), Sir Howard Stringer Chair, Sony Corporation), Charles Taylor (philosopher McGill), HJMB (neurologist to whom the Chancellor graciously came down to floor level), William Phillips (Physicist-Nobel Laureate from Maryland). A remarkable collection. (Figure 2)

Received July 11, 2013. Final Revisions Submitted July 15, 2013. Correspondence to: Henry J.M. Barnett, Suite 701, 305 Balliol Street, Toronto, Ontario, M4S 3H5, Canada. Email: hjmb@bell.net. 


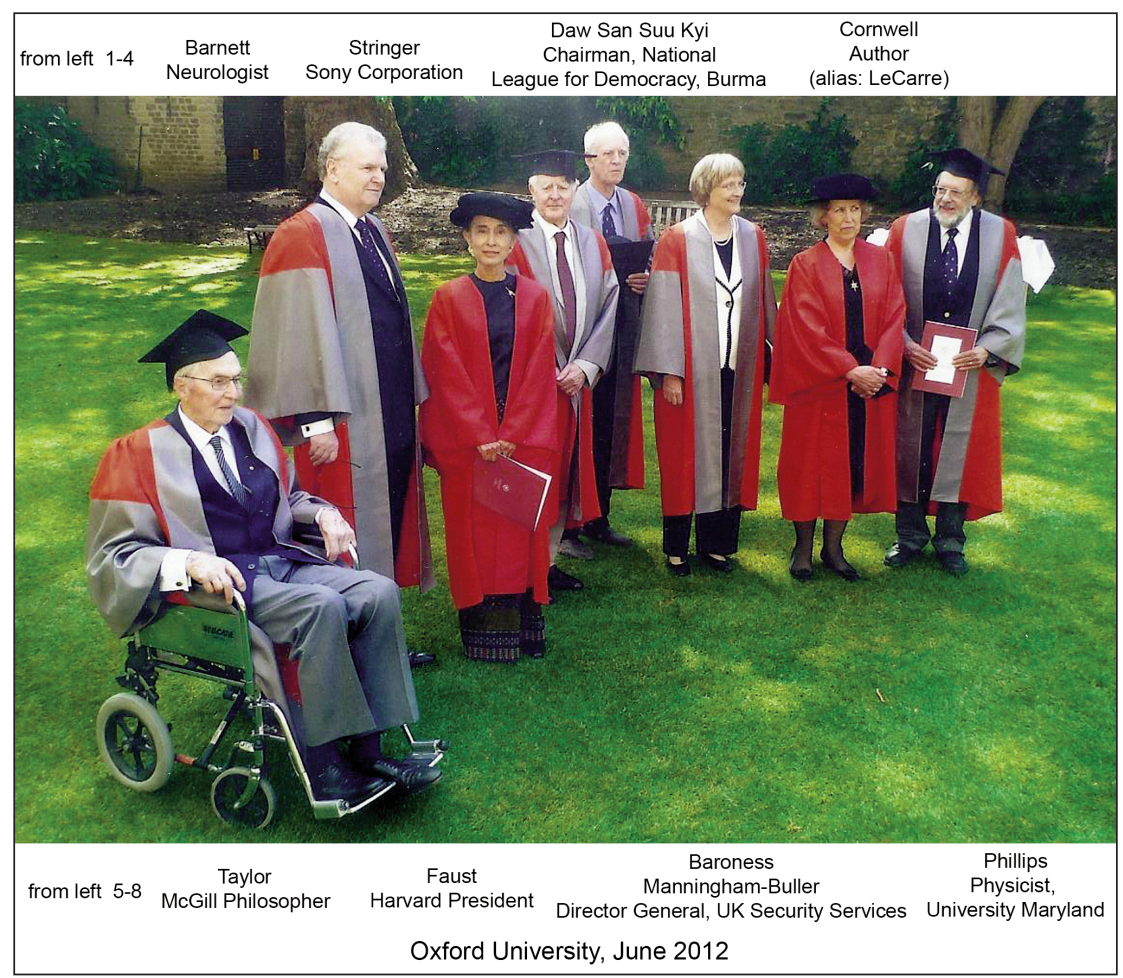

Figure 2: Henry Barnett (Neurology), Sir Howard Stringer (Chair, Sony Corporation), Daw San Suи Kyi (Chairman, National League for Democracy, Burma), David Cornwell (Penname Le Carre), Charles Taylor (philosopher McGill), Madam Drew Faust, (President of Harvard University), Baroness Manningham-Buller (UK Security Service), William Phillips (Physicist-Nobel Laureate from Maryland).

The citations were printed in the program in English and in Latin. In presenting each to the Chancellor the "reader", a classics scholar, described us to him in fluent Latin the careers of all eight of us.

At the conclusion of the conferring of the doctorate degrees (one in Civil Law, four in Letters and two in Science) we then proceeded to St. Hugh's College for a sumptuous Chancellor's lunch, Oxford's Lord Mayor presented Daw Suu with the Freedom of Oxford.

At lunch my sons and I were surrounded by old friends and former colleagues who worked with me at Queen Square in Toronto or London -- all now heads of departments or of medical schools, one now Professor and Head in Florence Italy, one Dean in Calgary, one a previous Head of Neurology at the Mayo Clinic, and now CEO of the Clinic. After lunch we went to a Garden Party at Worcester College in a park-like setting. Sir Richard Peto and I shared a glass of wine. His bio statistical skills had helped me by making evidence-seeking trials feasible. I had twobrief visits with Joanne McCormick, Egle Inzitari and Angelika Buchan. Sir Roger Bannister, an old Q.S. acquaintance and fellow-neurologist, was an invitee in his capacity as President of one of the Colleges. Lord Walton and I studied together in London in our youth. He added great pleasure as always. The next day he was invited to a special combined session of both Houses of UK Parliament to hear Daw Suu speak. The following day she dined with the new President of
France. I became and remain in her spell! One of the world's bravest and determined women and confirmed believer in nonviolent change. I told her that she ranked with one of my other three heroes. She responded that she did not rank with Gandhi, Martin Luther King nor Mandela; "They all accomplished, I am only trying." What a trial period!!

This remarkable day ended by a push in my chair to a dinner at Corpus Christi College hosted by Alastair Buchan (Oxford's Dean of Medicine); a great host and friend of many years.

Thus ended a couple of days comparable to none others in my first 90 years!

This addendum to my now printed Memoirs was sparked by a unique happening in June 2012 that must be added as the "Memoir of the Oxford trip." As the eight of us lined up for honorary degrees, a citation was read out in Latin for each, fortunately with an English version in the proceedings of the Encaenia. By my colleagues I was persuaded to reproduce here my own citation from the Proceedings:

"Dr Henry Barnett, CC, MD, was born in England and emigrated to Canada as a child (age 3). He graduated from the University of Toronto Medical School (age 17) before undertaking postgraduate training in neurology in Toronto, London and Oxford, where he worked with Charles Symonds, Hugh Cairns and Richard Doll. He was a member of Toronto's neurology faculty from 1952 to 1969 , in 1967 he founded the Department of Neurosciences at Sunnybrook Hospital and two 
years later co- founded the world's first multi-disciplinary department of clinical neurosciences at the University of Western Ontario. He was chairman of the department from 1974 until 1986 when he co-founded (with Charles Drake) the Robarts Research Institute which he led for eight years. Dr. Barnett oversaw the first randomized trial across Canada to establish the efficacy of aspirin in stroke prevention. This landmark study published in 1976 not only showed that it was possible to prevent stroke but also demonstrated the necessity of robust methodology in such clinical trials.

Subsequently he ran two large stroke trials: the first disproved the value of cerebral bypass surgery to prevent stroke, at the time one of the most common surgical procedures in the United States; the second, in conjunction with a separate European study, established which patients were most likely to benefit by carotid artery surgery to prevent stroke. He is currently Professor Emeritus at the University of Western Ontario.

His hundreds of publications include the standard stroke reference work: Stroke: Pathophysiology, Diagnosis and Treatment. He is a Companion of the Order of Canada. His many other honors include the 2008 Karolinska Award for Excellence in Stroke Research, the highest award for stroke research and honorary degrees from the University of Western Ontario, Dalhousie and Utrecht Universities and the New York Institute of Technology.

Stroke is a cause of universal anxiety for there is surely no one who does not have friends or family who have been assailed by its ravages or maybe suffered attack himself. So anyone who, like the man you now see before you, has found ways of prevention it is rightly hailed as a friend of the human race. Once more I present one of Canada's most distinguished citizens; this one though, was born in our country at Newcastle upon Tyne. He is amused by the thought that the building in which he was born became a home of ill repute; however his own father was a clergyman, whose appointment as a bishop took him and his family across the Atlantic. The son came back to England after finishing his training and worked for a time here in Oxford before returning home again. There his many discoveries soon made him a legend. He demonstrated that some strokes which had been previously attributed to cardiac events were actually brought about by narrowing of the arteries. He and his colleagues were the first to prove that the humble aspirin could not only serve to soothe minor discomfort but could also provide the arterial system with a measure of protection. But, useful though this pill may be, it could not prevent all strokes, so he and many colleagues sought further for a cure and found that if the carotid arteries like blocked drains could be cleared out, blood would flow more freely to the brain and combat the risk of attack. He also taught the scientific community how the use of randomized trials could show the relative risk impact of such factors as age, blood pressure or diabetes. Accordingly, he is by general consent the world's leading stroke neurologist. A nature lover and a passionate bird watcher, a loving and beloved grandfather and great-grandfather, he now enjoys a well-earned retirement in rural Ontario, but to adapt Virgil.

\section{In his years were seen A youthful vigor and autumnal green}

I present a most distinguished hierophant of Hippocrates, Henry Joseph Macaulay Barnett, CC, founder and former director of the Robarts Research Institute, to be admitted to the honorary degree of Doctor of Science.

Final words of Oxford's Chancellor:

Eminent master of the medical art, to whose work so many owe health and life itself, I on my own authority admit you to the honorary degree of Doctor of Science. 